\title{
METABOLIC AND ANTIRHEUMATIC ACTIVITIES OF 6-METHYL-PREDNISOLONE (MEDROL)
}

\author{
BY \\ EDWARD W. BOLAND AND GRANT W. LIDDLE \\ From the Department of Medicine, St. Vincent's Hospital, Los Angeles, California, and \\ the Department of Medicine, Vanderbilt University School of Medicine, Nashville, Tennessee
}

(RECEIVED FOR PUBLICATION AUGUST 6, 1957)

During the past few years a concerted effort has been made to develop synthetic derivatives of hydrocortisone and cortisone which would retain their anti-inflammatory activity but would be devoid of certain of their unwanted physiologic effects. Hope that analogues with enhanced therapeutic indices could be synthesized has stemmed from the knowledge that several properties of the naturally occurring hormones may be modified, sometimes selectively, by making changes in their chemical structures.

Since 1953 a number of significant innovations have been made in the synthesis of corticosteroid analogues. The first was the introduction, by Fried and Sabo (1953) and Fried (1955), of halogen atoms at the 9th carbon position of the steroid nucleus. The resulting 9-alpha-halogen corticosteroids were in most respects very much more potent than cortisone and hydrocortisone. For example, the potency of 9-alpha-fluorohydrocortisone was found to be ten times that of hydrocortisone with respect to anti-inflammatory, glycogenic, eosinopenic, ACTH-suppressing, and nitrogenwasting activities (Boland, 1955; Liddle, Richard, and Tomkins, 1956). But the electrolyte activity (sodium retention, potassium loss) of the fluoro compound has been found to be at least 125 times that of hydrocortisone, a feature which has precluded its application systemically as an antiphlogistic agent.

Another important chemical transformation in the steroid nucleus was the introduction, by Herzog, Nobile, Tolksdorf, Charney, Hershberg, Perlman, and Pechet (1955), of a double bond between carbon atoms 1 and 2 of cortisone and hydrocortisone. The compounds so derived, prednisone and prednisolone, have been found to be approximately four times as potent as their predecessors in anti-inflammatory, glycogenic, ACTH-suppressing, nitrogen-losing, and related properties. However, the 1-dehydro-analogues have exhibited no such increase in electrolyte activity and the partial dissociation of this effect has made them useful therapeutically. Clinical experience with prednisone and prednisolone has demonstrated, however, that they share most of the other shortcomings of the older steroids and, according to some investigators, they have seemed to promote such complications as peptic ulcers and ecchymotic skin lesions with greater frequency (Bunim, Pechet, and Bollet, 1955; Bollet, Black, and Bunim, 1955; Boland, 1956). Hence the quest for more suitable anti-inflammatory steroids has continued.

Hogg, Lincoln, Jackson, and Schneider (1955) and Spero, Thompson, Magerlein, Hanze, Murray, Sebek, and Hogg (1956) synthesized a series of methylated corticosteroids. Biologic experiments with these compounds indicated that when a methyl radical was substituted for a hydrogen atom at the second carbon position of the steroid nucleus, the sodium-retaining and potassium-losing effects of 11-hydroxy-corticosteroids were enhanced (Spero and others, 1956; Byrnes, Barnes, Bowman, Dulin, Morley, and Stafford, 1956). But if the methyl grouping were introduced at the 6th carbon position instead, no such increase in electrolyte activity resulted. Preliminary studies in animals with one of the methyl derivatives (6-alpha-methyl-prednisolone) suggested that this compound might have therapeutic promise. Lyster, Barnes, Lund, Meinzinger, and Byrnes (1956) and Glenn, Stafford, Lyster, and Bowman (1957) found the rat-liverglycogen depositing activity of the compound to be sixteen times that of hydrocortisone on oral administration and ten times that of hydrocortisone on subcutaneous administration; the potency ratio of 6-methyl prednisolone to prednisolone was calculated as $3: 1$. The anti-inflammatory potency of 
6-methyl-prednisolone, as gauged by the granulomapouch procedure of Selye, was 5.5 times that of hydrocortisone and twice that of prednisolone. Its mean biologic half-life in dogs was determined to be 1.56 and 1.14 times that of hydrocortisone and prednisolone respectively. Sodium and water retention did not develop in rats at any dose level tested.

\section{Present Investigation}

The data derived from studies in animals appeared sufficiently interesting to warrant evaluations of 6-alpha-methyl-prednisolone in human subjects. Observations of certain metabolic changes induced by the compound were made by one of us (G.W.L.) and clinical trials in patients with rheumatoid arthritis were conducted by the other (E.W.B.). The studies were accomplished independently and the results were then integrated for this report.

Metabolic Studies.-Detailed analyses were carried out in seven subjects (three normal men, three normal women, and one 20-year-old woman with gonadal agenesis) while they were being maintained on a constant dietary intake. Complete collections of urine over 24-hr periods were analysed for sodium and potassium (by flame photometry), for nitrogen (by semi-micro-Kjeldahl technique), for 17-hydroxycorticoids (by the method of Silber and Porter (1954), modified by Peterson, Wyngaarden, Guerra, Brodie, and Bunim, 1955), and for 17-ketosteroids (Zimmerman reaction, described by Callow, Callow, and Emmens, 1938, following hydrolysis and extraction by the method of Drekter, Heisler, Scism, Stern, Pearson, and McGarack, 1952). Determinations made during control periods and during the oral administration of 6-methyl-prednisolone and of prednisolone were compared. The steroids were administered in either three or four equally divided doses throughout the day. In various subjects the total daily dosage of each steroid ranged from $7 \cdot 5$ to $60 \mathrm{mg}$.

Assays of eosinopenic activity after single oral doses of 6-methyl-prednisolone and of prednisolone were accomplished in four normal adult subjects. Each subject received each steroid twice in doses of $2.5 \mathrm{mg}$. and twice in doses of $10 \mathrm{mg}$. Dosages were given at random, but an interval of at least $72 \mathrm{hrs}$ was allowed between individual doses. Decision as to the size and spacing of doses was prompted by preliminary observations which indicated that for both steroids a linear log-dose response relationship existed between dosages of $2 \cdot 5$ and $10 \mathrm{mg}$., and that recovery from a single dose of steroid tested occurred within 24 hrs. Circulating eosinophils were counted before and at 4 and 7 hours after each dose of steroid. The percentage de- $\frac{5}{3}$ creases in eosinophils at 4 and 7 hours were calcu- lated, and the average of the two values was con-? sidered as the numerical response.

Assays of the electrolyte-regulating activities of $\frac{\text { क }}{0}$ 6-methyl-prednisolone and of prednisolone were $\frac{C}{0}$ accomplished in adrenalectomized dogs by the $\overline{\frac{0}{0}}$ method of Liddle, Cornfield, Casper, and Bartter $\overparen{\mathbb{D}}$ (1955).

Clinical Studies.-6-methyl-prednisolone was ad- $\stackrel{\text { c }}{\vec{\circ}}$ ministered under various conditions to 41 patients with active peripheral rheumatoid arthritis in order $\vec{\omega}$ to ascertain:

(1) Responses of the disease manifestations in $\frac{0}{2}$ patients who had not previously received $\vec{\sigma}$ corticosteroid therapy;

(2) Relative antirheumatic potency of the drug, $\underset{\sim}{\omega}$ per milligram, as compared with prednisolone; $\stackrel{\oplus}{-}$

(3) Differences from prednisone and prednisolone, if any, in the tendency for the drug to promote undesirable side-reactions.

Observations were made in ten patients who were given 6-methyl-prednisolone as their first steroid तु therapy. The general plan for dosage was the same $\frac{3}{0}$ as we have applied in the past with hydrocortisone, $\stackrel{\mathbb{D}}{-}$ prednisone, and prednisolone. This consisted $8 \overrightarrow{0}$ initial suppressive doses followed by gradual redug tion of dosage to maintenance levels. Because previous experience with steroid therapy had demor strated that long-range results were best (especially in regard to the avoidance of adverse hormonal effects) when initial suppressive amounts were not $\stackrel{\circ}{\mathcal{O}}$ too large, an attempt was made in each instance to $\cong$ begin treatment with dosages which did not exceed $\overrightarrow{\vec{O}}$ greatly the estimated ultimate maintenance dose. $\exists$ The size of the initial doses used was determined principally by the activity of the disease process in individual cases and ranged from $7 \cdot 5$ to $12.5 \mathrm{mg}$. per day. 6-methyl-prednisolone was administered by mouth, and the total daily requirement was divided into four doses ingested at mealtimes and at bedtime with milk or a small quantity of food. Adjustments in dosage were made by small incre- 0 ments or decrements of 1.25 or $2.5 \mathrm{mg}$. at a time. Complemental therapy, other than routine general $\frac{7}{0}$ measures (such as regulated rest and exercise, well-balance diet, etc.), was withheld during the $\mathcal{N}$ study. All patients were ambulatory. The total $N$ treatment periods for the group ranged, at the time of analysis, from 12 to 27 weeks.

Comparisons of doses required for 6-methylprednisolone and for prednisolone to uphold approximately equivalent degrees of improvement $\mathscr{D}$ were made in a total of nineteen patients. The method consisted of transferring patients from one 
compound to another and determining the number of milligrams of each substance needed to maintain a similar clinical response. Among the nineteen patients studied, each was subjected to at least two comparisons, and some to as many as four or five. Transfers of medication were made back and forth from 6-methyl-prednisolone to prednisolone, time being allowed in each instance to stabilize dosage and response with the preparation tested.

\section{Results of Investigation}

Electrolyte Activity.-In human subjects who received total oral dosages of $15 \mathrm{mg}$. per day, neither 6-methyl-prednisolone nor prednisolone caused significall retention of sodium (Fig. 1, and Figs 2, 3, and 4, overleaf).

A moderate increase in the excretion of potassium was usually noted on the first day of treatment with either steroid. Withdrawal of either steroid was followed by diminished potassium excretion for one or two days.

Studies of the sodium-retaining and potassiumactivities of these two compounds in adrenalectom- ized dogs suggested that the electrolyte-regulating effect of 6-methyl-prednisolone may have been slightly less than that of prednisolone; the 6-methylanalogue was observed to be 0.6 times as potent as prednisolone (mean estimate). However, the 95 per cent. confidence limits for the estimate were 0.4 to 1.1. Therefore the data do not exclude the possibility that the two steroids may exert identical influences on electrolyte metabolism.

Nitrogen Excretion.-With total doses of $15 \mathrm{mg}$. per day, both 6-methyl-prednisolone and prednisolone induced increases in urinary nitrogen (Figs 1, 2, 3, and 4). In all studies, 6-methyl-prednisolone appeared to be at least as active as prednisolone as a nitrogen-wasting agent.

ACTH Suppression.-It has been assumed that decreases in urinary 17,21-dihydroxy-20-ketosteroids (17-hydroxycorticoids) which follow the administration of corticoids are secondary phenomena due to suppressed secretion of pituitary adrenocorticotropic hormone (ACTH). When certain corticoids, including 6-methyl-prednisolone

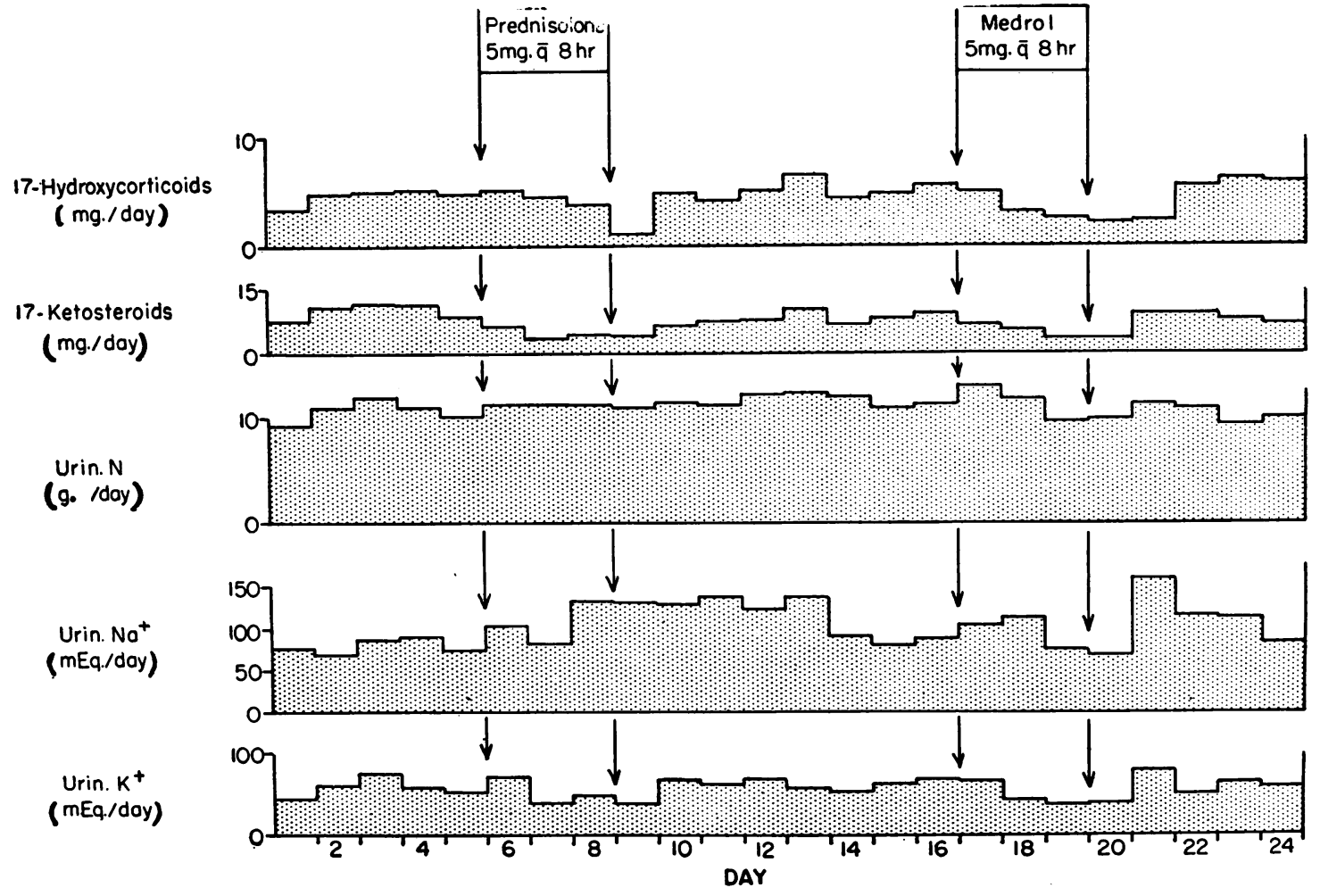

Fig. 1.-Some metabolic effects of prednisolone and of 6-methyl-prednisolone administered orally to a normal subject maintained on a constant diet. 


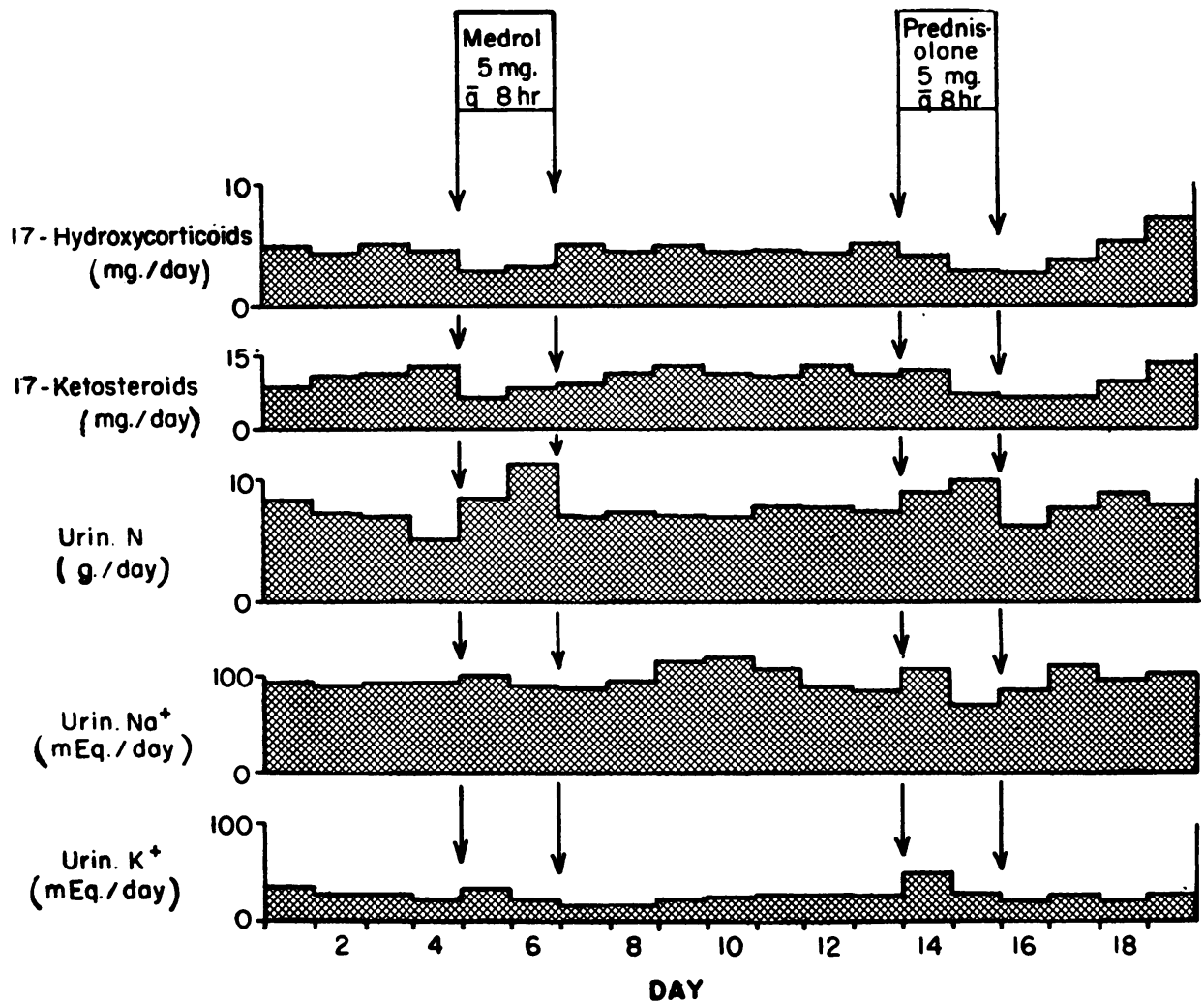

Fig. 2.-Some metabolic effects of prednisolone and of 6-methyl-prednisolone administered orally to a patient with gonadal agenesis maintained on a constant diet.

and prednisolone, are given exogenously, they are excreted in part as 17-hydroxycorticoids. Account must be taken of the contribution of these compounds themselves to the total urinary quantity of 17-hydroxycorticoids when the degree of suppressed pituitary-adrenal function is determined. From earlier and separate studies it was found that approximately 10 per cent. of an administered dose of 6-methyl-prednisolone and 25 per cent. of a dose of prednisolone can be expected to appear in the urine as 17-hydroxycorticoids.

When the urinary values for 17-hydroxycorticoids (Figs 1, 2, 3, and 4) were corrected by subtracting the amounts estimated as being contributed by the exogenously administered compounds, it was judged that both 6-methyl-prednisolone and prednisolone, given in doses of $15 \mathrm{mg}$. per day, almost completely inhibited pituitary-adrenal function. 17-ketosteroid excretion fell sharply with both steroids, a finding which also may be attributed to suppression of ACTH secretion.
Eosinopenic Activity.-Reductions in the numbers of circulating eosinophils which followed the administration of equal milligram amounts of the two steroids differed but slightly. The mean estimate suggested that 6-methyl-prednisolone was $1 \cdot 1$ times as effective as prednisolone. The 95 per cent. confidence limits on this estimate of the ratio of potency were 0.7 to $1 \cdot 6$.

Antirheumatic Response in Patients receiving 6-methyl-prednisolone as Initial Therapy.--The immediate response of rheumatic manifestations to 6-methyl-prednisolone was qualitatively similar to that which has been observed characteristically with other effective anti-inflammatory steroids. The rapidity and degree of improvement were at least as marked as would have been anticipated with similar milligram doses of prednisone or prednisolone. The improvement status after 12 to 27 weeks of continuous therapy was adequate (marked or very marked) in seven of the ten patients (Table I, opposite). 


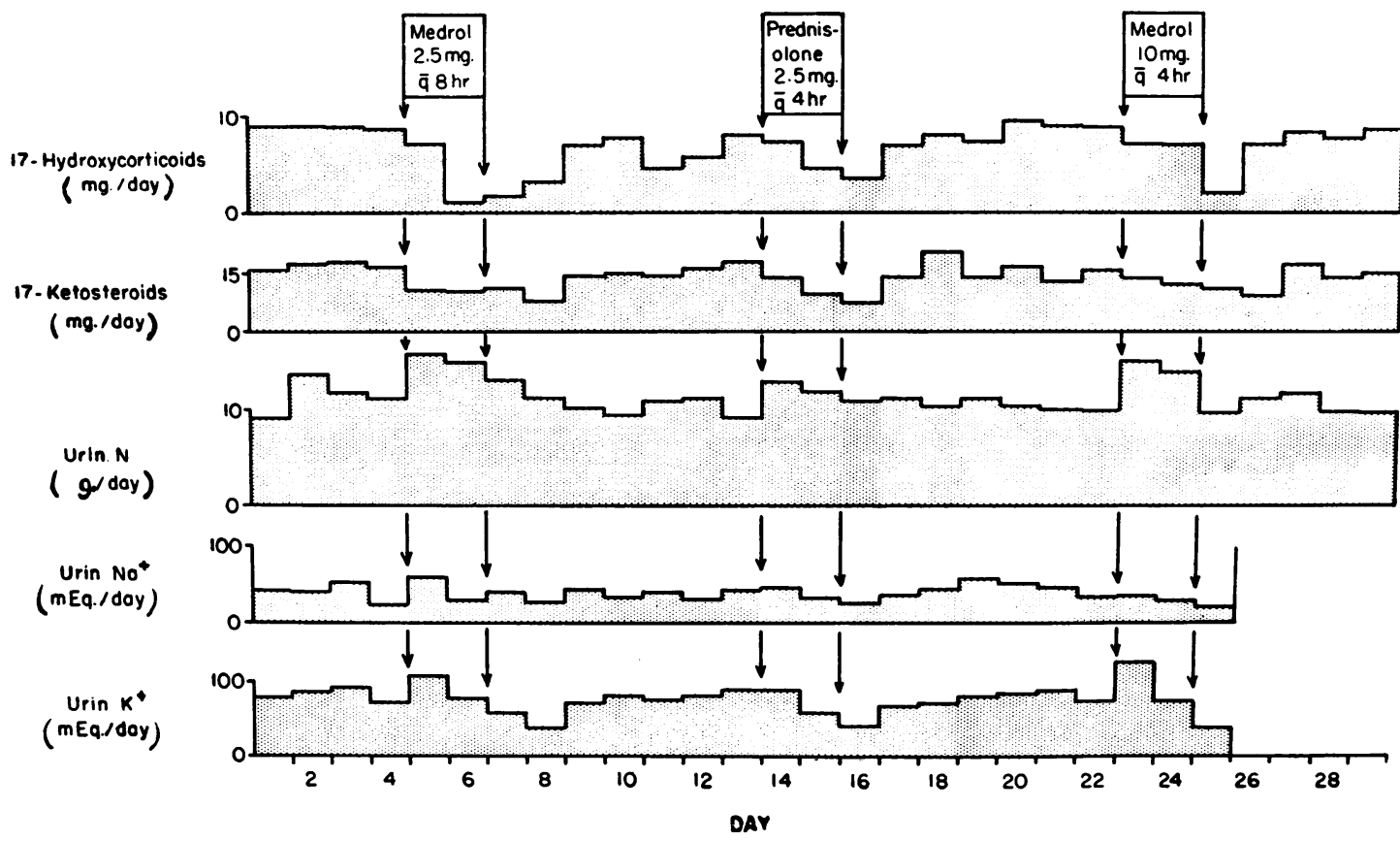

Fig. 3.- Some metabolic effects of prednisolone and of 6-methyl-prednisolone administered orally to a normal subject maintained on a constant diet.

TABLE I

RESULTS IN TEN PATIENTS RECEIVING 6-METHYL-PREDNISOLONE AS INITIAL THERAPY

\begin{tabular}{|c|c|c|c|c|c|c|c|c|}
\hline \multirow{2}{*}{$\begin{array}{l}\text { Patient } \\
\text { No. }\end{array}$} & \multirow{2}{*}{ Sex } & \multirow{2}{*}{$\begin{array}{l}\text { Disease } \\
\text { Severity }\end{array}$} & \multicolumn{2}{|c|}{ Dosage (mg./day) } & \multirow{2}{*}{$\begin{array}{l}\text { Duration of } \\
\text { Treatment } \\
\text { (weeks) }\end{array}$} & \multirow{2}{*}{$\begin{array}{l}\text { Degree of } \\
\text { Improvement } \\
\text { (at Analysis) }\end{array}$} & \multirow{2}{*}{\multicolumn{2}{|c|}{$\begin{array}{c}\text { Adverse Hormonal Side-Effects } \\
\text { (at Analysis) }\end{array}$}} \\
\hline & & & Initial & Maintenance & & & & \\
\hline 1 & $\mathbf{F}$ & Moderate & $10 \cdot 0$ & $7 \cdot 5$ & 20 & Very marked & & \\
\hline 2 & $\mathbf{F}$ & $\begin{array}{l}\text { Moderately } \\
\text { Severe }\end{array}$ & $10 \cdot 0$ & $10 \cdot 0$ & 13 & Moderate & & \\
\hline 3 & $\mathbf{F}$ & Moderate & $7 \cdot 5$ & $6 \cdot 25$ & 13 & Marked & $\begin{array}{l}\text { Facial mooning } \\
\text { Supraclavicular fat pads }\end{array}$ & $\begin{array}{l}\text { Moderate } \\
\text { Mild }\end{array}$ \\
\hline 4 & $\mathbf{F}$ & Severe & $12 \cdot 5$ & $10 \cdot 0$ & 16 & Moderate & $\begin{array}{l}\text { Facial mooning } \\
\text { Supraclavicular fat pads }\end{array}$ & $\begin{array}{l}\text { Moderate } \\
\text { Moderate }\end{array}$ \\
\hline 5 & $\mathbf{F}$ & Moderate & $7 \cdot 5$ & $5 \cdot 0$ & 26 & Very marked & $\begin{array}{l}\text { Facial mooning } \\
\text { Hypertrichosis }\end{array}$ & $\begin{array}{l}\text { Mild } \\
\text { Mild }\end{array}$ \\
\hline 6 & $\mathbf{F}$ & $\begin{array}{l}\text { Moderately } \\
\text { Severe }\end{array}$ & $10 \cdot 0$ & $7 \cdot 5$ & 26 & Very marked & $\begin{array}{l}\text { Facial mooning } \\
\text { Hypertrichosis } \\
\text { Ecchymotic skin lesions }\end{array}$ & $\begin{array}{l}\text { Mild } \\
\text { Moderate } \\
\text { Moderate }\end{array}$ \\
\hline 7 & $\mathbf{F}$ & $\begin{array}{l}\text { Moderately } \\
\text { Severe }\end{array}$ & $10 \cdot 0$ & $7 \cdot 5$ & 25 & Very marked & Facial mooning & Mild \\
\hline 8 & $\mathbf{F}$ & $\begin{array}{l}\text { Moderately } \\
\text { Severe }\end{array}$ & $10 \cdot 0$ & $5 \cdot 0$ & 26 & Marked & $\begin{array}{l}\text { Facial mooning } \\
\text { Supraclavicular fat pads } \\
\text { Hypertrichosis }\end{array}$ & $\begin{array}{l}\text { Moderate } \\
\text { Moderate } \\
\text { Moderate }\end{array}$ \\
\hline 9 & $\mathbf{M}$ & $\begin{array}{l}\text { Moderately } \\
\text { Severe }\end{array}$ & $7 \cdot 5$ & $0 \cdot 25$ & 27 & Very marked & $\begin{array}{l}\text { Facial mooning } \\
\text { Ecchymotic skin lesions }\end{array}$ & $\begin{array}{l}\text { Moderate } \\
\text { Moderate }\end{array}$ \\
\hline 10 & $\mathbf{F}$ & Moderate & $7 \cdot 5$ & $6 \cdot .5$ & 12 & Moderate & & \\
\hline
\end{tabular}




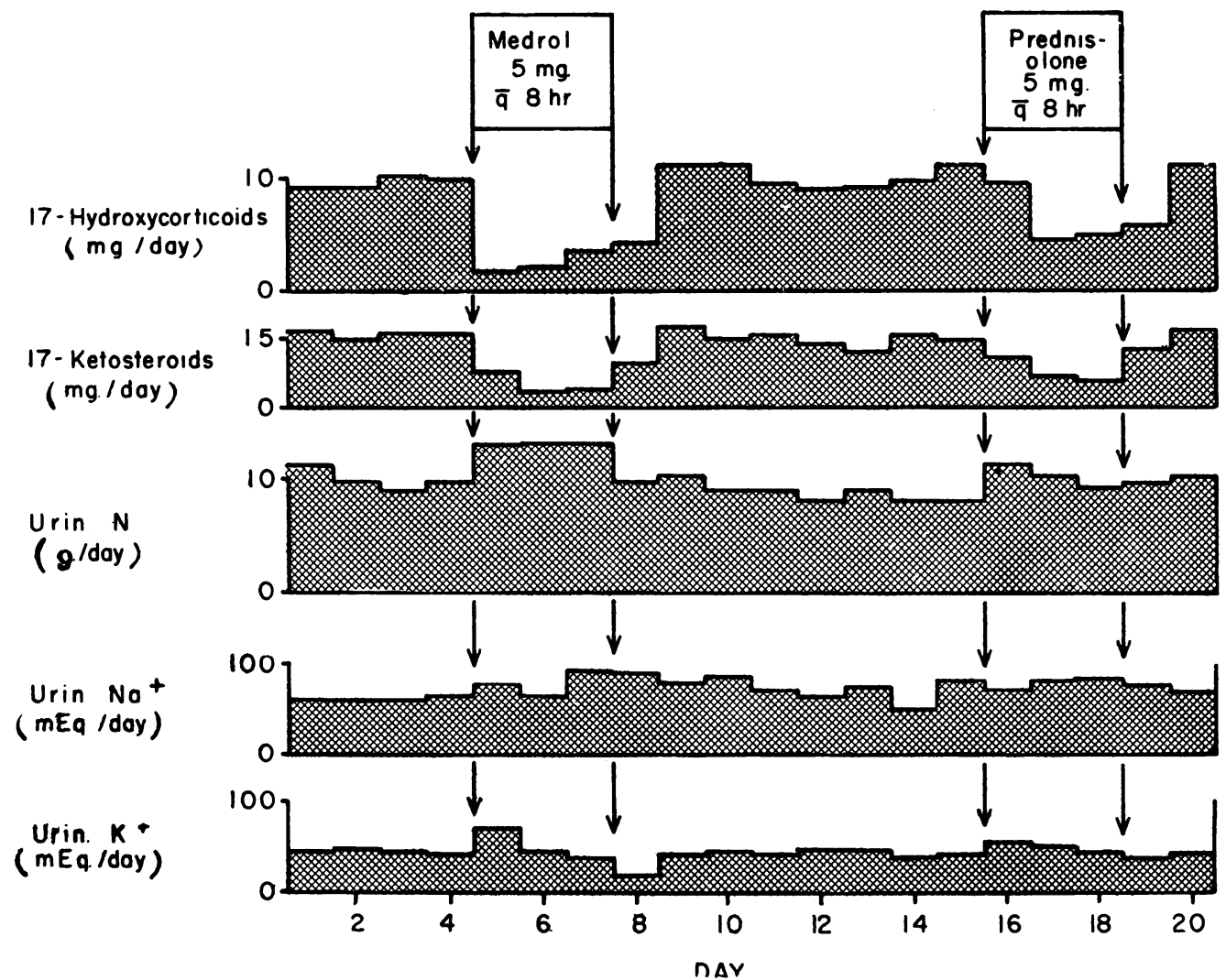

Fig. 4.-Some metabolic effects of prednisolone and of 6-methyl-prednisolone administered orally to a normal subject maintained on a constant diet.

The degree of improvement was comparable to that which might be expected from prednisone or prednisolone given for similar treatment periods.

Antirheumatic Potency of 6-methyl-prednisolone as compared with that of Prednisolone.-The results of comparisons of doses required to uphold similar degrees of clinical improvement are summarized in Table II (opposite). As far as could be determined on a clinical basis, 6-methrl-prednisolone and prednisolone were equally effective in eleven of the nineteen patients, and equivalent degrees of rheumatic control were provided by somewhat lower - dosages of 6-methyl-prednisolone in the eight remaining patients. The average dosage ratio of 6-methyl-prednisolone to prednisolone was $1: 1 \cdot 13$ for the group-a variance so small that one could not state, on the basis of clinical comparisons, that the two compounds actually differed in antirheumatic potency, per milligram.

Adverse Physiologic Reactions from 6-methylprednisolone. - The small number of patients studied and the relatively short periods of observation permit only tentative conclusions in respect to unwanted side-effects as compared with prednisone or prednisolone. Among ten patients who received 6-methylprednisolone as initial treatment. seven demonstrated mild to moderate signs of Cushing's syndrome at the time of analysis, facial mooning developed in seven, supraclavicular fat pads in three, hypertrichosis in three, and purpuric skin lesions in two (Table I).

Twelve patients with various undesired sideeffects resulting from long-term treatment with prednisone or prednisolone were selected and transferred to 6-methyl-prednisolone therapy. The individual reactions noted before and 8 to 20 weeks after the transfer of medication are recorded in Table III (overleaf). Minor differences in the degree of some reactions, in one direction or the other, were noted in some patients after the substitution of the new compound, but the changes were inconstant and most could be explained by the variations which are always prone to occur during steroid 
TABLE II

COMPARISONS OF MILLIGRAM DOSAGES OF 6-METHYL-PREDNISOLONE AND PREDNISOLONE REQUIRED FOR EQUIVALENT DEGREES OF RHEUMATIC CONTROL IN NINETEEN PATIENTS

\begin{tabular}{|c|c|c|c|c|c|}
\hline \multirow{2}{*}{ Patient No. } & \multirow{2}{*}{ Disease Severity } & \multicolumn{2}{|c|}{$\begin{array}{l}\text { Dosages (mg./day) for } \\
\text { Equivalent Rheumatic Control }\end{array}$} & \multirow{2}{*}{$\begin{array}{l}\text { Dosage Ratios } \\
\text { 6-Methyl-Prednisolone } \\
\text { to Prednisolone }\end{array}$} & \multirow{2}{*}{$\begin{array}{l}\text { Potency Ratios } \\
\text { 6-Methyl-Prednisolone } \\
\text { to Prednisolone }\end{array}$} \\
\hline & & $\begin{array}{l}\text { 6-Methyl- } \\
\text { Prednisolone }\end{array}$ & Prednisolone & & \\
\hline 1 & Severe & $15 \cdot 0$ & $15 \cdot 0$ & $1: 1$ & $1: 1$ \\
\hline 2 & Moderately Severe & $10 \cdot 0$ & $10 \cdot 0$ & $1: 1$ & $1: 1$ \\
\hline 3 & Moderately Severe & $7 \cdot 5$ & $10 \cdot 0$ & $1: 1 \cdot 33$ & $1 \cdot 33: 1$ \\
\hline 4 & Moderate & $5 \cdot 0$ & $7 \cdot 5$ & $1: 1 \cdot 5$ & $1 \cdot 5: 1$ \\
\hline 5 & Moderately Severe & $7 \cdot 5$ & $7 \cdot 5$ & $1: 1$ & $1: 1$ \\
\hline 6 & Moderately Severe & $15 \cdot 0$ & $15 \cdot 0$ & $1: 1$ & $1: 1$ \\
\hline 7 & Moderate & $7 \cdot 5$ & $10 \cdot 0$ & $1: 1 \cdot 33$ & $1 \cdot 33: 1$ \\
\hline 8 & Moderately Severe & $7 \cdot 5$ & $10 \cdot 0$ & $1: 1 \cdot 33$ & $1 \cdot 33: 1$ \\
\hline 9 & Moderate & $10 \cdot 0$ & $10 \cdot 0$ & $1: 1$ & $1: 1$ \\
\hline 10 & Moderately Severe & $10 \cdot 0$ & $12 \cdot 5$ & $1: 1 \cdot 25$ & $1 \cdot 25: 1$ \\
\hline 11 & Moderately Severe & $7 \cdot 5$ & $10 \cdot 0$ & $1: 1 \cdot 33$ & $1 \cdot 33: 1$ \\
\hline 12 & Severe & $10 \cdot 0$ & $12 \cdot 5$ & $1: 1 \cdot 25$ & $1 \cdot 25: 1$ \\
\hline 13 & Moderately Severe & $12 \cdot 5$ & $12 \cdot 5$ & $1: 1$ & $1: 1$ \\
\hline 14 & Moderately Severe & $5 \cdot 0$ & $10 \cdot 0$ & $1: 2$ & $2: 1$ \\
\hline 15 & Severe & $10 \cdot 0$ & $10 \cdot 0$ & $1: 1$ & $1: 1$ \\
\hline 16 & Moderately Severe & $10 \cdot 0$ & $10 \cdot 0$ & $1: 1$ & $1: 1$ \\
\hline 17 & Moderate & $7 \cdot 5$ & $7 \cdot 5$ & $1: 1$ & $1: 1$ \\
\hline 18 & Moderate & $7 \cdot 5$ & $7 \cdot 5$ & $1: 1$ & $1: 1$ \\
\hline 19 & Moderately Severe & $10 \cdot 0$ & $10 \cdot 0$ & $1: 1$ & $1: 1$ \\
\hline Average & 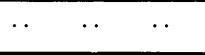 & $9 \cdot 2$ & $10 \cdot 4$ & $1: 1 \cdot 13$ & $1 \cdot 13: 1$ \\
\hline
\end{tabular}

administration, and, in the case of increases, by the additional periods of treatment. These observations suggested that the unwanted physiologic reactions from the compound did not differ significantly from those which develop from prednisone or prednisolone. The study was not sufficiently extensive in numbers of patients or in duration of therapy to permit an assessment of the relative proclivity of 6-methyl-prednisolone to promote such complications as peptic ulcer or osteoporosis.

\section{Comment}

Our observations indicate that in human subjects the anti-inflammatory and the other physiologic effects of prednisolone are not altered significantly by the substitution of a methyl radical at the sixth carbon position. From the standpoint of practical therapeutic application, 6-methyl-prednisolone appeared to exhibit no obvious advantages over prednisolone; in fact, the two compounds were found to exert similar antirheumatic responses from milligram doses which were interchangeable. Although dis- appointing, these results should not discourage a continued search for more effective antirheumatic steroid compounds. It is essential that knowledge be obtained of how each chemical permutation in the formula of the naturally occurring corticosteroids influences their various physiological properties. Only from such information will the relationship between the structural configuration and the biological activities of new synthetic steroids be determined, and the discovery of compounds possessing higher therapeutic indices be brought closer.

These findings emphasize the disparity which may exist between assessments of anti-inflammatory activity in human subjects and in laboratory animals. The screening of new steroid compounds for their potential clinical value begins (and often ends) with assays of several physiological effects in laboratory animals. While these screening tests are essential, it is important to realize that with animal tests one is often not measuring precisely the same physiological effects as one wishes to produce in human 
TABLE III

COMPARISON OF ADVERSE HORMONAL SIDE-EFFECTS DURING PREDNISOLONE OR PREDNISONE THERAPY AND AFTER TRANSFER OF MEDICATION TO 6-METHYL-PREDNISOLONE

(TWELVE SELECTED CASES)

\begin{tabular}{|c|c|c|c|c|c|c|c|c|c|c|c|c|c|c|c|c|c|c|c|c|}
\hline \multirow{3}{*}{$\begin{array}{l}\text { Pa- } \\
\text { tient } \\
\text { No. }\end{array}$} & \multirow{3}{*}{ Sey } & \multicolumn{2}{|c|}{$\begin{array}{l}\text { Usual Total Daily } \\
\text { Maintenance Dose }\end{array}$} & \multirow{3}{*}{$\begin{array}{c}\text { Duration } \\
\text { of } \\
\text { 6-Methyl- } \\
\text { Predni- } \\
\text { solone } \\
\text { Admini- } \\
\text { stration } \\
\text { (wks) }\end{array}$} & & & \multicolumn{4}{|c|}{ Individual Adverse Side } & \multicolumn{4}{|c|}{-Effects Before and After } & \multicolumn{4}{|c|}{ Transfer of Medication $\ddagger$} & & \\
\hline & & \multirow{2}{*}{$\begin{array}{c}\text { Predni- } \\
\text { sone or } \\
\text { Predni- } \\
\text { solone } \\
\text { (mg.) }\end{array}$} & \multirow{2}{*}{$\begin{array}{l}\text { 6- } \\
\text { Methyl- } \\
\text { Predni- } \\
\text { solone } \\
\text { (mg.) }\end{array}$} & & \multicolumn{2}{|c|}{$\begin{array}{l}\text { Facial } \\
\text { Mooning }\end{array}$} & \multicolumn{2}{|c|}{$\begin{array}{l}\text { Supra- } \\
\text { clavicular } \\
\text { Fat Pads }\end{array}$} & \multicolumn{2}{|c|}{ Oedema } & \multicolumn{2}{|c|}{$\begin{array}{l}\text { Hyper- } \\
\text { trichosis }\end{array}$} & \multicolumn{2}{|c|}{$\begin{array}{c}\text { Ecchymotic } \\
\text { Skin } \\
\text { L.esions }\end{array}$} & \multicolumn{2}{|c|}{$\begin{array}{l}\text { Digestive } \\
\text { Symptoms }\end{array}$} & \multicolumn{2}{|c|}{$\mid \begin{array}{c}\text { Vaso- } \\
\text { motor } \\
\text { Symptoms }\end{array}$} & \multicolumn{2}{|c|}{$\begin{array}{c}\text { Raised } \\
\text { Blood } \\
\text { Pressure }\end{array}$} \\
\hline & & & & & $\mathbf{P}$ or $\mathbf{P}$ & $6 \mathrm{MP}$ & P or P & $6 \mathrm{MP}$ & $\mathbf{P}$ or $\mathbf{P}$ & $6 \mathrm{MP}$ & Por $\mathbf{P}$ & $6 \mathrm{MP}$ & Por $\mathbf{P}$ & $6 \mathrm{MP}$ & P or $\mathbf{P}$ & $6 \mathrm{MP}$ & $\mathbf{P}$ or $\mathbf{P}$ & 6MP & Por $\mathbf{P}$ & $6 \mathrm{MP}$ \\
\hline 1 & $\mathbf{F}$ & $7 \cdot 5$ & $5 \cdot 0$ & 13 & * & $\begin{array}{l}\dagger \\
2\end{array}$ & 3 & 3 & & & 2 & 2 & & 2 & & & & & & \\
\hline 2 & $\mathbf{F}$ & $12 \cdot 5$ & $12 \cdot 5$ & 13 & 1 & 2 & 1 & 1 & & & 1 & 1 & & 2 & & & & & & \\
\hline 3 & $\mathbf{F}$ & $10 \cdot 0$ & $10 \cdot 0$ & 14 & 3 & 4 & 2 & 3 & 1 & 1 & 3 & 3 & 1 & 3 & 1 & 1 & & & 1 & 1 \\
\hline 4 & $\mathbf{F}$ & $10 \cdot 0$ & $7 \cdot 5$ & 10 & 2 & 2 & 1 & 1 & & & & & & & & & 2 & 2 & & \\
\hline 5 & $\mathbf{F}$ & $7 \cdot 5$ & $7 \cdot 5$ & 8 & 2 & 2 & 1 & 1 & & & & & 1 & 1 & & & & & & \\
\hline 6 & $\mathbf{F}$ & $15 \cdot 0$ & $15 \cdot 0$ & 8 & 2 & 2 & 2 & 2 & & & & & 3 & 3 & 1 & 1 & & & & \\
\hline 7 & $\mathbf{M}$ & $15 \cdot 0$ & $15 \cdot 0$ & 8 & 4 & 4 & 3 & 3 & 2 & 2 & & & 4 & 4 & & & & & 2 & 2 \\
\hline 8 & $\mathbf{F}$ & $10 \cdot 0$ & $12 \cdot 5$ & 8 & 2 & 2 & 1 & 1 & 2 & 2 & 1 & 1 & 2 & 2 & & & & & & \\
\hline 9 & $\mathbf{F}$ & $10 \cdot 0$ & $12 \cdot 5$ & 8 & 3 & 3 & 2 & 2 & 1 & 1 & 1 & 1 & 2 & 2 & 2 & 2 & 2 & 2 & 2 & 2 \\
\hline 10 & $\mathbf{F}$ & $7 \cdot 5$ & $7 \cdot 5$ & 13 & 2 & 2 & & 1 & & & 2 & 2 & & & & & 2 & 2 & & \\
\hline 11 & $\mathbf{F}$ & $10 \cdot 0$ & $10 \cdot 0$ & 20 & 2 & & & & & & 2 & 2 & 2 & 2 & & & & & & \\
\hline 12 & $\mathbf{F}$ & $10 \cdot 0$ & $7 \cdot 5$ & 20 & 1 & 2 & & 1 & & & & & & & & & 1 & 1 & & \\
\hline
\end{tabular}

patients. It is now evident, for example, that the relative effectiveness of steroid compounds in suppressing the manifestations of rheumatoid arthritis cannot be predicted reliably by the degree of inhibition of granuloma-pouch formation or by the degree of liver-glycogen deposition in rats. The present study was prompted by the observation that 6-methyl-prednisolone was twice as potent as prednisolone as an "anti-granuloma" agent in ratsyet clinically the compound appeared to have activity indistinguishable from that of prednisolone as an "antirheumatic" agent. It is apparent that the difficult task of screening the numerous synthetic analogues of hydrocortisone and cortisone, available now and in the future, would be greatly facilitated if more dependable laboratory tests for measuring anti-inflammatory potency could be devised.

\section{Summary}

The metabolic and antirheumatic effects of a new steroid analogue, 6-methyl-prednisolone, were studied in human subjects. Preliminary screening tests made in animals suggested that the compound might possess greater anti-inflammatory potency than prednisolone and perhaps augmented therapeutic efficacy. The results of the present study indicated, however, that the new compound differed in no essential from prednisolone itself.

Studies of certain metabolic effects of 6-methylprednisolone led to the following deductions:

(1) The sodium-retaining and potassium-losing activities of the compound may be slightly (but not conclusively) less than those of prednisolone.

(2) The compound appeared to be at least as powerful as prednisolone as a nitrogen-wasting agent.

(3) The compound produced the same degree of pituitary-adrenal functional inhibition as prednisolone when the two substances were given in equal milligram dosages.

(4) Reductions in the numbers of circulating eosinophils after the administration of equal milligram amounts of the new compound and of prednisolone did not differ significantly.

Clinical observations resulting from the administration of 6-methyl-prednisolone in 41 patients with active peripheral rheumatoid arthritis led to the following deductions:

(1) The character and degree of improvement in rheumatic manifestations resulting from the administration of 6-methyl-prednisolone in patients receiving the drug as initial therapy did not differ significantly from those which would be anticipated from prednisone or prednisolone given in similar milligram doses. 
(2) Direct comparisons of the dosages of 6-methylprednisolone and prednisolone required to uphold similar degrees of clinical improvement suggested that the two compounds possessed little, if any, difference per milligram in antirheumatic potency.

(3) Only tentative conclusions could be drawn regarding unwanted side-effects from the new compound as compared with prednisone or prednisolone. However, most of the adverse reactions observed from the latter compounds were also observed with 6-methyl-prednisolone. The study was not sufficiently extensive to assess the relative tendency of the new compound to promote such complications as peptic ulcer or osteoporosis.

The 6-methyl-prednisolone (Medrol) and prednisolone used in these studies were supplied by the Upjohn Company, Kalamazoo, Michigan. The metabolic studies were supported in part by grants-in-aid from the John A. Hartford Foundation and the National Institutes of Health (CY-3107). The clinical studies were supported in part by a grant from the Ahmanson Foundation. The technical collaboration of Mr. Donald Island is gratefully acknowledged.

\section{REFERENCES}

Boland, E. W. (1955). Ann. N.Y. Acad. Sci., 61 [art. 2], 591. (1956). J. Amer. med. Ass., 160, 613.

Bollet, A. J., Black, R., and Bunim, J. J. (1955). Ibid., 158, 459.

Bunim, J. J., Pechet, M. M., and Bollet, A. J. (1955). Ibid., 157, 311.

Byrnes, W. W., Barnes, L. E., Bowman, B. J., Dulin, W. E., Morley, E. H., and Stafford, R.O. (1956). Proc. Soc. exp. Biol. (N.Y.) 91, 67.

Callow, N. H., Callow, R. K., and Emmens, C. W. (1938). Biochem. J., 32, 1312 .

Drekter, I. J., Heisler, A., Scism, G. R., Stern, S., Pearson, S., and McGavack, T. H. (1952). J. clin. Endocr., 12, 55.

Fried, J. (1955). Ann. N.Y. Acad. Sci., 61 [art.], 573.

Fried, J. (1953). J.Amer. chem, Soc, 75, 2273.

Glenn, E. M., Stafford, R. O., Lyster, S. C., and Bowman, B. J. (1957) Annals of the Rheumatic Diseases, 16, 139

Herzog, H. L., Nobile, A., Tolksdorf, S., Charney, W., Hershberg, E. B., Perlman, P. L., and Pechet, M. M. (1955). Science, $121,175$.

Hogg, J. A., Lincoln, F. H., Jackson, R. W., and Schneider, W. P. (1955). J. Amer. chem. Soc., 77, 6401.

Liddle, G. W., Cornfieid, J., Casper, A. G. T., and Bartter, F. C. (1955). J. clin. Invest., 34, 1410.

Richard, J. E., and Tomkins, G. M. (1956). Metabolism 5, 384 .

Lyster, S. C., Barnes, L. E., Lund, G. H., Meinzinger, M. M., and Byrnes, W. W. (1957). Proc. Soc. exp. Biol. (N.Y.), 94, 159.

Peterson, R. E., Wyngaarden, J. B., Guerra, S. L., Brodie, B. B., and Bunim, J. J. (1955). J. clin. Invest., 34, 1779.

Silber, R. H., and Porter, C. C. (1954). J. biol. Chem., 210, 923.

Spero, G. B., Thompson, J. L., Magerlein, B. J. Hanze, A. R., Murray, H. C., Sebek, O. K., and Hogg, J. A. (1956). J. Amer. chem. Soc., 78, 6213 .

\section{Action métabolique et antirhumatismale de la 6-méthyl-prednisolone (Medrol)}

\section{RÉSUMÉ}

On a étudié sur des sujets humains les effets métaboliques et antirhumatismaux d'un nouveau analogue stéroïde, la 6-méthyl-prednisolone. Des essais préalables sur des animaux avaient fait penser que ce composé aurait un pouvoir anti-inflammatoire supérieur à celui de la prednisolone et que son efficacité thérapeutique serait aussi plus grande. Les résultats de ces études indiquent, cependant, que le nouveau produit ne diffère sur aucun point essentiel de la prednisolone originale.

Les études de certains effets métaboliques de la 6méthyl-prednisolone mènent à des déductions suivantes :

(1) L'action sur les ions métalliques-rétention sodique et perte potassique-de ce composé est peutêtre un peu (et non pas définitivement) plus faible que celle de la prednisolone.

(2) Le dépérissement d'azote avec ce composé semble être au moins aussi prononcé qu'avec la prednisolone.

(3) Aux doses égales, en milligrammes, le degré d'inhibition de la fonction surréno-pituitaire es le même pour les deux substances.

(4) Il n'y a pas de différence appréciable dans le pouvoir des deux substances, en doses égales, de réduire le nombre des éosinophiles sanguins.

L'observation clinique de 41 malades atteints d'arthrite rhumatismale périphérique active, traités par la 6-méthylprednisolone, permet des déductions suivantes:

(1) Le caractère et le degré de l'amélioration des manifestations rhumatismales obtenue à la suite de l'administration de la 6-méthyl-prednisolone à titre de thérapie initiale ne différait pas significativement de celle qu'on aurait obtenue avec la prednisone ou la prednisolone, si l'on avait donné ces substances en quantités de milligrammes égales.

(2) La comparaison directe des quantités de 6-méthylprednisolone et de prednisolone nécessaires pour maintenir le même degré d'amélioration clinique suggère que le pouvoir antirhumatismal des deux substances au poids égal en milligrammes est presque, ou tout à fait, égal.

(3) On ne peut tirer que des conclusions tentatives en ce qui concerne les effets secondaires nuisibles du nouveau composé par rapport à la prednisone et la prednisolone. On peut dire, cependant, que la plupart des réactions défavorables de ces substances ont aussi été notées avec la 6-méthyl-prednisolone. Les recherches n'ont pas été poussées assez loin pour déterminer la tendance relative du nouveau composé à provoquer des complications telles que l'ulcère peptique ou l'ostéoporose.

\section{Acción metabólica y antirreumática de la 6-metil-prednisolona (Medrol)}

\section{SUMARIO}

Los efectos metabólicos y antirreumáticos de un nuevo análogo esteroide, la 6-metil-prednisolona, fueron estudiados en sujetos humanos. Investigaciones preliminares sobre animales habían sugerido que este compuesto pudiera tener un poder anti-inflamatorio superior al de la prednisolona y que su eficacidad terapéutica fuera también mayor. Los resultados de los estudios presentes indican, sin embargo, que el producto nuevo no se distingue esencialmente de la prednisolona original.

Las investigaciones de ciertos efectos metabólicos de la 6-metil-prednisolona nos llevan a las conclusiones siguientes:

(1) La acción sobre los iones metálicos-retención de sodio y pérdida de potasio-de este compuesto es, quizás (pero no conclusivamente), algo más debil que la de la prednisolona.

(2) El desgaste de nitrógeno con este compuesto parece ser al menos tan pronunciado como él con la prednisolona.

(3) En dosis iguales de miligramos, el grado de inhibición de la función hipofiso-suprarrenal es igual para ambos compuestos. 
(4) No hay diferencia apreciable en el poder de estas substancias, en cantitades iguales, de reducir el número de eosinófilos circulantes.

La observación clínica de 41 enfermos con artritis reumatoide periférica activa, tratados con la 6-metilprednisolona, permite las conclusiones siguientes:

(1) El carácter y el grado de la mejoría de las manifestaciones reumáticas obtenida con la 6-metil-prednisolona en la terapia inicial no diferían de los que se hubiera podido anticipar con la prednisona o la prednisolona, si las cantidades administradas de estas substancias, miligramo por miligramo, fueran iguales.

(2) La comparación directa de la cantidades de 6-metil-prednisolona ye de prednisolona necesarias para mantener el mismo grado de mejoría clínica sugiere que el poder antirreumático de cada producto a peso igual en miligramos es casi, o enteramente, igual.

(3) Se llegó tan sólo a conclusiones tentativas respecto a efectos secundarios nocivos del compuesto nuevo en comparación con la prednisona y la prednisolona. Se puede decir, sin embargo, que la mayoría de tales efectos observados con estos productos se vió también con la 6-metil-prednisolona. Estas investigaciones no fueron bastante extendidas para determinar la tendencia relativa del nuevo compuesto a provocar complicaciones del tipo de úlcera péptica o de osteoporosis. 